\title{
LVII. Statistical account of the quicksilver mines of Idria in Illyria
}

\section{Paysse}

To cite this article: M. Paysse (1815) LVII. Statistical account of the quicksilver mines of Idria in Illyria, Philosophical Magazine Series 1, 46:210, 306-312, DOI: 10.1080/14786441508638547

To link to this article: http://dx.doi.org/10.1080/14786441508638547

曲 Published online: 27 Jul 2009.

Submit your article to this journal $₫$

Џll Article views: 2

Q View related articles ¿ 
and this will be a true method of preventing these nations from massacring their prisoners of war, as the king of Dahomet does at the present moment. May our feeble voice on this subject reach the ear of royalty!

LVII. Statistical Accontnt of the Quicksiluer Mines of Idria in Illy'ria. By M. PAYsse, Superintendant of the Manufacture of Mercurial Productions".

$\mathrm{T}$ HF authors who have written upon Idria, and among whom we may reckon Walter Pope, Edward Brown, Walvasor, Frederick Stampfer, Scopoli, Ferber and Hacquet, are generally agreed as to the ora of the discovery of this mine, which they date in 1497.

It is suid that towards the end of the thirteenth century the valley and basin of Idria were covered with wood; that the situation had a savage appearance, two peasants only having huts there, and which were even far distant from each other.

One of these peasants, who we are told was a kind of cooper, having one day placed a tub under a spring of water which issued from the hillock on which the church of St. Trinity has subsequently been erected, found at the bottom of the vessel, when he emptied it, some globules of a white metallic substance, which struck him with astonishment. On returning home he coliected this substance, and carried it to a jeweller in the little town of Bischofflaach, about four leagues off. The jeweller, having ascertained that the substance was mercury, employed every method of knowing from the peasant the place where he found it : but neither promises nor rewards could induce him to reveal his secret.

What the jeweller could not effect was obtained by a peasant named Cazian Auderlin, who promised to assist the discoverer as a partner in working the mine. In fact, these two peasants began their researches; and being contented with some very slight excarations in the schistous soil which contained the metal, they soon ceased to find the mercury in a native state, and they abandoned their labours.

Already, however, some peasants in the neighbourhood had become acquainted with the labours of our two miners; and scarcely had the latter desisted, when the former, guided by views of interest, united, and undertook digging in their turn : buit being as ignorant as those who preceded them as to the nature of the bodies with which the mercury was united in the bowels

* Annales de Chimie, tome xci. p. 161. 
of the earth, they ceased their researches when they no longer found this metal in the liquid state, or in' the form of cinnabar.

A company of mining adventurers succeeded, guided by the hopes of better success, and instructed by scientific men, anong whom the names of Witig Tholhauser and Florian Thater occur. This company commenced a series of operations suited to the state of knowledge at the time: they opened a vertical well for extracting the produce (which is still shown by the name of St. Agatha) on the side opposite to the first experiments.

In 1510 the Venetians, in making war upon the people who inhabited the Frioul, in which Idria is situated, seized the works by force of arms. 'This conquest, however, was not of long duration; for soon afterwards Maximilian, emperor of Germany, who was then at war with the Venetians, retook the country, and restored the mines of Idria to the original proprietors.

In 1525 a catastrophe destroyed the greater part of the result of fifteen years labours. A violent earthquake threw down almost the whole of the galleries; mountains which skirted along the valley were thrown down and precipitated into the torrent called the Idrixa, the course of which was changed in some places : and this unexpected accident ruined the company of miners.

The next adventurers were from Saltzburg; and about the year 1572 the labours were resumed with new activity, and in a regular manner.

In 1575 the Archduke Charles of Austria took possession of the mines as a conqueror, and he was the first who set about creating a regular administration for the benefit of the state.

Francis Toichel, who was sent as deputy from the Government to establish it, dug the vertical pit known by the name of Santa Barba: he contrived furnaces for separating the mercury from the substances which mineralize it in the bowels of the earth, and suggested the mixing of the sulphuret of mercury with lime, in order to isolate the metal from the sulphur. It was he also who gave the first ideas of the fabrication of saline mercurial productions.

The administration of Idria was then composed of a president who was chief director, five counsellors, and a secretary.

In 1803 a fire broke out in the inside of the mines, and occasioned great damage; but by the sage counsels of M. Fihold, who then directed the subterranean works, its ravages were stopped by introducing water into the interior. Several persons were suffocated in the act of assisting their comrades. M. Vorauer, sub-engineer, remained a long time insensible, but was 
at length restored to life; and M.Scherowitz the chief accomptant was dreadfully burnt.

It was in 1809 , as a consequence of the treaty of Znaim, that the mines of Idria as part of the Illyrian provinces came into the possession of France; and the French administration lasted until 1813 , when the Austrians occupied these provinces by force of arms.

The town and quicksilver mines of Idria are situated in $31^{\circ}$ $33^{\prime}$ longitude, and $46^{\circ} 16^{\prime}$ latitude, about twelve leagues north from Trieste, and twelve leagues north-east from Gorice.

Under the Austrian regime, Idria was a scignory dependent on the circle of Adlerberg.

Under the French regime, this seignory was a canton, and a mayoralty composed as follows :

i. Town of Idria. 2. Village of Lower Idria. 3. Hamlets of High Canomla. 4. Middle Canomla. 5. Lower Canomla. 6. Carnitza. 7. Iellitsch Scheuwerk. S. Tschekounig: 9. Woiska. 10. Magdalenabery.

The extent of this domain is about two leagues and two-thirds of a league square, two-thirds of which are forests.

When I was mayor in 1812 , the population was 7060-of whom 4095 lived in the town of Idria alone.

The town of Idria is situated in an alnost conical basin. It is partly built of the rublish of the mine.

A small valley which rises at the well of Sagoda on the Idrixa, and which terminates at the mouth of the Canomla in Lower Idria, gives a course to the torrent of Idrixa, This torrent takes its source in the Julian Alps, about three leagues from the town. After passing through about nineteen leagues, and operating its junction with the torrent of the Canomla near Lower Idria, it throws itself into the Isonzo near Canale, not far from Gorice.

The small torrents of the Trehuschanka, the Zalla, the Nicova, and some subterranean springs which flow near the mill of Sagoda, at least double the volume of the waters of Idrixa. Without these kinds of springs, which are very abundant in all seasons, and which alone are sufficient for putting in motion the various wheels of the above mill, it is certain that the workmen of the Idrian establishment would want a moving power during summer, in order to put in motion the hydraulic wheels of the machinery for the mercurial preparations.

The torrent of Canomla (already mentioned) is greatly increased by the waters of the torrent of the Woitschiack, and by those of some subterranean springs which issue near the mouth of this last torrent.

The little valley of Canomla is more open and more extensive than 
than that of the Idrixa ; there are more cultivable grounds, and particularly meadows, in it.

Sluices for retaining the water destined for floating the timber necessary for the service of the mines have been made on several of those torrents; and the French during their short administration erected one on that of the Woitschiack, which is distinguished from the rest by its solidity and elegant construction. It was just finished under the care of General Andreossy when the French evacuated Idria in 1813.

Among the torrents which swell the Idrixa, there are none truly permanent but those of the Canomla and the Zalla, and even the latter is often dry in summer.

The narrow valley through which the Idrixa flows is bounded by two chains of mountains, the mean height of which measured barometrically is about 288 fathoms. They are in general calcareous, of the kind called transition. All these calcareous masses are frequently intersected by very much inclined strata of argillaceous schistus, particularly in the environs of Bas Idria. These schists somet:mes contain very thin layers of beautifully white laminar quartz, and frequently also carbonated lime.

In other parts there are schists strongly depressed, reticular and curvilinear, in thicker strata, mixed alternately with quartz and carbonated lime of a decided whiteness. Every thing shows in this singular arrangement, that these various strata have undergone a slow or instantaneous pressure at the moment of their formation, and at epochs when these masses still possessed a certain degree of softness. This formation is particularly remarkable at the back of the mountain, the interior of which is mined, and which overhangs the canal the water of which feeds the pumping engines of the wells of St. Barba and St. Agatha. We find it also in the section of the chain against which the furnaces are situated, and in the ravines made by the waters, as well as in many other parts in ascending or descending the Idrixa.

Banks of a coarse gres, and a kind of breche almost entirely quartzous, are seen on the road which leads from the church of St. Trinity to that of Calvary; parts are decomposed by their exposure to the air; others resist its influence, and are not changed by the action of the most violent heat produced by large bellows. Thick strata of an argilo-calcareous schist frequently cover these siliceous masses.

The manganesiated argil, in which we meet with masses or detached pieces of sulphuretted iron, sometimes crystallized, are often found exposed in certain ravines of these chains, which the water produced by the melting of the snows seems to have laid bare. 
The mineralogy of the mayoralty, although not very rich or various, nevertheless exhibits carbonated lime in great varieties. We find also black and gray marble very compact and of very close texture, as well as breches' susceptible of a very fine poJish.

The valley of Canomla furnishes white marble; saccharine carbonated lime, similar to the statuary marble of Carrara, the grain of which is not quite so compact; a carbonated lime containing alumine or stalactite in masses, a species of cavernous tuf, very useful for constructing, arches. We there also find marls and argils of various colours, adapted for the potter and brickmaker; amorphous quartz in banks, very considerable in the vicinity of Trebuschanka, and crystallized in the confines of Tolmino and Walmistrate. Jaspers of various colours in thick layers are found in the country of Woiska : they appeared to be inclined strongly on the side of the torrent of I'rebuschanka, where we observe their superficial decomposition in a very marked manner. There is also a kind of freestone (botb fine- and coarsegrained) in the environs of the forest called Razore; coal freestone (gres houilliers) in the little valley of Tschekourig, as well as in the vicinity, where there have been excavations, asd where there are traces of fossil coal.

Calcareous thumacheles susceptible of polish, shells agglomerated by an argillaceous paste containing sulphuretted iron, which is decomposed in the air, accompany the substances which have been extracted from the excavations practised at the time of the search for coal.

Amphibolic rocks and micaceous schists are found in several places.

Sulphurated iron inclosed in lumps in argil, oxide of the same metal, in this earthy substance, forming the luminous manganeseformed iron, is disseminated in the district of Pouschenick, in strata, the thickness of which has not been examined.

Finally, native mercury combined with various matters forms the chief mineral riches of this country.

I have already observed that the town of Idria was built at the hottom of the conical basin and over the subterraneous works. Its height above the level of the sea is, according to the various barometrical measurements which I have made, 169 metres.

Although the town of Idria is not regularly built, it is nevertheless pleasing to the eye. 'The houses in which the workmen live, far from being distinguished by a black and dismal look as is usual in the vicinity of mines, seem on the contrary, from their external neatness, to indicate that the inhabitants enjoy ease and comforts not usual among this class of workmen in other countries. 
Two or three principal buildings are here remarkable:-a fine parish church, and a castle for accommodating the chief director of the mines, and for containing the treasure; the magazine for the products of the mine; the hall of the council of administration; and all the public offices; a very fine granary or store-house for the inhabitants as well as for the workmen; a very fine forge; some houses for those employed by Goverument, for the curé and his vicars, \&c.

There is also a public school with six professors, and a female to superintend the education of the young girls; a very fine hospital, to which two physicians and surgeon are attached, and a dispensary for giving medicines to the sick. These were among the improvemeits executed under the inspection of the French.

'The situation of the town of Irlia does not expose it to the tempestuous winds which are common on the shores of the Adriatic. The Borra and Sirocco, which are the most violent of the season, pass above the chain which overhangs Idria, follow the course of the torrent, and are consequently but very little felt by the inhabitants: the air, however, is not stagnant; for it is constantly renewed in consequence of the vicinity of forests, an active vegetation, and a rapid torrent. It is remarked that a current exists constantly in the atmosphere, from the direction taken by the vapours which rise from the furnaces for the distilation of mercury, and those for the fabrication of mercurial productions.

The variations of the barometer are neither very frequent nor very considerahle at Idria. The mean height of the mercury, according to my observations for four years, on a barometer of the diameter of eight lines, was 27 inches 5 lines *.

The seasons are less iuconstant at Idria than in many other countries of the globe : they are generally rainy in autumn, very cold and snowy in winter. Thunder storms are very frequent during summer, and there are sometimes two or three in a day; or rather the great atmospherical currents carry them there.

The snow covers the mountains of Idria as well as the valley nearly six months in the year, and is often five feet deep: the great road from Layback to Idria is then intercepted; and the acministration is forced to employ three or four hundred workmen to clear it, in order to convey provisions to the population.

* It may be of importance to remark that an instrument of a large diameter is requisite for observations which require great precision. The uscillations of the mercury in large diameters are constantly more sensible and more regular: attraction and thermometrical effects may also be regarded as insensible in these large instruments. 
The cold weather although of long duration is not severe; but the thermometer rarely descends to 15 degrees below zero of Reaumur. The heat of summer is frequently oppressive. The mountains which form this basin being generally calcareous, and almost entirely devoid of wood; these masses are easily heated, and reflect the calorific rays in the town with great intenseness: the rocks, therefore, particularly those with a south exposure, contain a great number of serpents, vipers, lizards, and insects in great variety. The red viper is very common there.

[To be continued.]

\section{Notices respecting New Books.}

$M_{R}$. Thomas Forster has it in contemplation to publish, in the course of a fow months, and to continte periodically, a work entitled "Sournal de Mélćorologie, avec d' Olservations sur les Phénomènes de l'Atmosphère," \&c. \&c. Mr. Luke Howard and other meteorologists have promised their occasional assistance. The object of the work will be to publish journals of meteorology kept in various parts of Europe ; together with occasional essays on subjects immediately connected with this science, The publication and the period of the appearance of the first number of the work will depend on the suecess the gentlemen concerned in the work meet with, in receiving journals and other communications from abroad, Letters on meteorolngy, notices of meteors and other occasional phænomena, besides regular journals, are within the plan of the work. The principal object of this work is to collect accounts from abroad, and to communicate to the continent the discoveries made in this country.

Mr. Sowerby, the indefatigable naturalist, of No, 2, Mead Place, Lambeth, has published a most vahable Catalogue of coloured Drawings of English Medicinal Plants, as a Companion to the Materia Medica of the College of Physicians. The in= tention of $\mathrm{Mr}$. Sowerby in his present undertaking, is to make medical practitioners (whose knowledge of botany may not be extensive) acquainted with all the English plants which they may have occasion to use. We presume we shall gratify our medical and scientific readers highly by selecting the catalogue of mushrooms, as divided into eatable and poisonous, which $\mathrm{Mr}$. Sowerby has faithfully depicted in elegant coloured prints. The medicinal plants, strictly so called, are fifty-two in number; the mushrooms are seventeen in number, fourteen of which are eatable, and only three poisonous. Many fatal accidents have occurred, 